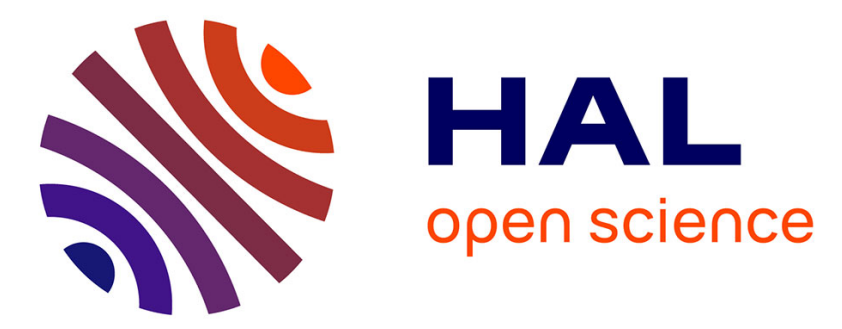

\title{
Effect of Temperature on Chloride Diffusion in Saturated Concrete
}

\author{
B. Touil, F. Ghomari, A. Bezzar, A. Khelidj, Sophie Bonnet
}

\section{To cite this version:}

B. Touil, F. Ghomari, A. Bezzar, A. Khelidj, Sophie Bonnet. Effect of Temperature on Chloride Diffusion in Saturated Concrete. Materials Journal, 2017, 114 (5), 10.14359/51688929 . hal-01923475

\section{HAL Id: hal-01923475 \\ https://hal.science/hal-01923475}

Submitted on 5 Dec 2018

HAL is a multi-disciplinary open access archive for the deposit and dissemination of scientific research documents, whether they are published or not. The documents may come from teaching and research institutions in France or abroad, or from public or private research centers.
L'archive ouverte pluridisciplinaire HAL, est destinée au dépôt et à la diffusion de documents scientifiques de niveau recherche, publiés ou non, émanant des établissements d'enseignement et de recherche français ou étrangers, des laboratoires publics ou privés. 
EFFECT OF TEMPERATURE ON CHLORIDE DIFFUSION IN SATURATED CONCRETE

\author{
B. Touil, Pr F. Ghomari, Dr A. Bezzar, Pr A. Khelidj, Dr S. Bonnet
}

Brahim Touil: Assistant Professor in the Civil Engineering Department, University of Saida, Algeria. Researcher-PhD student at EOLE laboratory of University of Tlemcen, Algeria, and GeM laboratory of IUT Saint Nazaire, Nantes University, France. His research interests include the durability of reinforced concrete structures in the marine environment.

Fouad Ghomari: Professor in the Civil Engineering Department and Director of EOLE Laboratory, University of Tlemcen. He is secretary of Chapter ACI of Algeria. His research interests include durability of reinforced concrete structures in the marine environment.

Abdelillah Bezzar: Assistant Professor in the Civil Engineering Department and EOLE Laboratory University of Tlemcen, Algeria, His research interests concrete durability, corrosion science and sustainable construction.

Abdelhafid Khelidj: Professor in the Civil Engineering Department Nantes University, GeM CNRS UMR 6183, IUT Saint Nazaire, France, His research interests Coupled transfers in cementitious materials, couplings and Durability of Concrete and Concrete behaviour to young and very young age.

Stephanie Bonnet: Assistant Professor in the Civil Engineering Department Nantes University, GeM CNRS UMR 6183, IUT Saint Nazaire, France, Her research interests sustainability and diffusion test chloride ions for cracked concrete.

\title{
ABSTRACT
}

The degradation of reinforced concrete structures exposed to marine environment is largely due to the transfer of chloride ions through the material. Indeed, the prediction of the 
penetration of these ions in the concrete by the diffusion coefficient is a fundamental indicator for the characterization of its durability. Actually, the tests simulating chloride diffusion in saturated areas are developed at constant temperature. However, in reality the temperature fluctuates with the seasons and diurnal variations. In order to simulate the coupled temperature-diffusion of chloride in reinforced concrete structures in permanent contact with the Mediterranean Sea, an experimental program was developed in the laboratory to assess the migration coefficients of a pozzolanic concrete (CPZ10) and compared to ordinary concrete referenced (OC). The tests of migration are made under electric field, at different temperatures from 5 to $50^{\circ} \mathrm{C}$ ( 41 to $122^{\circ} \mathrm{F}$ ). Also a study of the activation energy was made and compared with the Arrhenius theory. The test results showed that the migration coefficient of concrete increase with increasing temperature. The activation energy values of natural pozzolan incorporated concretes were lower than ordinary concrete.

Keywords: Concrete, Pozzolan, Coefficient of migration of chlorides, Temperature, Activation energy.

\section{INTRODUCTION}

The corrosion of steel reinforcements is a major cause of the degradation of reinforced concrete (RC) structures exposed to sea water. It is due to the ingress of chloride ions into concrete. Indeed, chlorides can penetrate through the porous media of concrete to reach embedded steel, which leads to depassivation and corrosion initiation. Corrosion of steel can start when a sufficient amount (i.e., the threshold) of chloride ions accumulates at the steel surface and breaks down the passive layer of iron oxide that developed due to the high alkalinity of the concrete medium ${ }^{1-2}$. This phenomenon depends on the speed of chloride penetration into concrete. This is conditioned by several factors such as the water/binder ratio 
1 (w/b), the age of concrete $^{3}$, the type of binder $^{4-6}$, the porosity ${ }^{7-8}$ and the environmental 2 conditions $^{9-10}$ (temperature, humidity, etc...). The temperature variations have a significant

3 effect on the properties of transfer, particularly on the kinetics of chloride diffusion ${ }^{9}$. Hence, it

4 is judicious to study the impact of the temperature variations on the process of chloride

5 diffusion in concrete.

6 During the last decades, several researchers have studied the chlorides diffusion coefficient 7 using different test methods ${ }^{11-14}$, standards ${ }^{15-16}$ and numerical prediction models ${ }^{17-19}$. It should 8 be noted here that the most of the studies focus on the chloride diffusion into cementitious 9 materials either on effective or apparent diffusion coefficient, at constant temperature ${ }^{20-23}$.

However, the temperature is a catalyst which acts on the kinetics of diffusion. The increase of the temperature accelerates the chloride diffusion because molecular speed increases with increasing temperature. In fact, high temperature may both decrease physical binding of chlorides because of higher thermal vibration and increase the content of chemically bound chloride ions, because of the increase in the speed of reactions ${ }^{9,24-27}$.

There are few studies concerning the apparent diffusion coefficient which took into account the temperature effect ${ }^{9-10,24-27}$. This effect was evaluated on samples subjected to heat treatment before chloride diffusion test or by using a test bench conditioned at desired temperature for immersion or transient diffusion/migration tests.

Some experimental results obtained in previous studies were explained by the theoretical equation based on the Arrhenius law using the concept of activation energy as shown in Eq. $(1)^{10,26}$. 
2 Where $\mathrm{D}(\mathrm{T})\left(\mathrm{m}^{2} / \mathrm{s}\right)\left(\mathrm{ft}^{2} / \mathrm{s}\right)$ and $\mathrm{D}\left(\mathrm{T}_{0}\right)\left(\mathrm{m}^{2} / \mathrm{s}\right)\left(\mathrm{ft}^{2} / \mathrm{s}\right)$ are the diffusion coefficients at $\mathrm{T}(\mathrm{K})(\mathrm{F})$

and $\mathrm{T}_{0}(\mathrm{~K})(\mathrm{F})$ respectively, $\mathrm{E}_{\mathrm{a}}(\mathrm{kJ} / \mathrm{mol})$ is the activation energy of diffusing of chloride transport in concrete, $\mathrm{R}(\mathrm{kJ} /(\mathrm{mol} . \mathrm{K}))(\mathrm{kJ} /(\mathrm{mol} . \mathrm{F}))$ is the ideal gas constant.

Collepardi et al. $^{28}$ studied the chloride diffusion into cement pastes containing natural pozzolan with water-cement ratio of 0.4 : the samples were put in contact with $\mathrm{CaCl}_{2}$ solution and kept at $10,25,40^{\circ} \mathrm{C}\left(50,77,104^{\circ} \mathrm{F}\right)$. The results shows that the pozzolanic cement paste offer a higher resistance to the $\mathrm{Cl}^{-}$penetration than the portland cement paste and the activation energy determined was $35.56 \mathrm{~kJ} / \mathrm{mol}$ for the cement paste and $4.12 \mathrm{~kJ} / \mathrm{mol}$ for the pozzolanic cement paste.

Goto et al. ${ }^{29}$ has determined a diffusion rates of chlorides ions as a function of several factors in hardened cement paste such as water-cement ratio, curing age, curing temperature and diffusion temperature $\left(27,35,45\right.$ and $\left.60^{\circ} \mathrm{C}\right)\left(80,95,113\right.$ and $\left.140^{\circ} \mathrm{F}\right)$ using a diffusion cell. It is reported there was a significant temperature dependence of apparent diffusion coefficient and they obtained the activation energy of $50.2 \mathrm{~kJ} / \mathrm{mol}$ with a water-to-cement ratio of 0.4 .

Page et al. ${ }^{30}$ investigated the cement paste and were using the cells diffusion placed in a water bath, with five values of temperature in the range 7 to $47^{\circ} \mathrm{C}\left(44.6\right.$ to $\left.116.6^{\circ} \mathrm{F}\right)$; the effective diffusion coefficient measured is affected by the level of temperature and they found that the activation energy was dependent on water-to-cement ratio (w/c), $41.8 \mathrm{~kJ} / \mathrm{mol}$ for paste with $\mathrm{w} / \mathrm{c}=0.4,44.6 \mathrm{~kJ} / \mathrm{mol}$ for paste with $\mathrm{w} / \mathrm{c}=0.5$, and $32.2 \mathrm{~kJ} / \mathrm{mol}$ for paste with $\mathrm{w} / \mathrm{c}=0.6$.

Nguyen et al. ${ }^{31}$ investigated the effect of temperature on chloride diffusion into mortars with cement type I and V using an accelerated test method. They found that chloride diffusion coefficient and penetration depth increase with temperature level. The activation energy are in the range of literature values ${ }^{30}$ : the values are $35.7 \mathrm{~kJ} / \mathrm{mol}$ and $32.3 \mathrm{~kJ} / \mathrm{mol}$ for the mortars incorporating cement type I and $\mathrm{V}$, respectively. 
1 Al-Khaja ${ }^{25}$ studied experimentally the durability performance of high-strength concrete mixes

2 and conventional concrete, exposed to chloride environments $(5 \% \mathrm{NaCl})$ at temperatures of

320 and $45^{\circ} \mathrm{C}\left(68\right.$ and $\left.113^{\circ} \mathrm{F}\right)$. The results noticed that a significant increase in the chloride

4 ingress into concrete was observed when the exposure temperature was increased from 20 to

$545^{\circ} \mathrm{C}\left(68\right.$ to $\left.113^{\circ} \mathrm{F}\right)$ in both conventional and high-strength concretes. Furthermore, the effect

6 of temperature on chloride ingress is more influential in the conventional concrete than in the

7 high-strength concrete. The activation energy was not determined in this study. Samson and

8 Marchand $^{32}$ proposed a semi empirical function, to estimate variations in diffusion coefficient

9 of concrete when the temperature of the material fluctuates with the values of 4,23 and $40^{\circ} \mathrm{C}$ (39.2, 73.4 and $\left.104^{\circ} \mathrm{F}\right)$. The activation energy obtained from migration test is ranging from 17.9 to $21.2 \mathrm{~kJ} / \mathrm{mol}$.

Yuan et al. ${ }^{26}$ also studied the temperature effect on the transport of chloride ions in concrete with different water-cement ratio and type of cement. The investigation was carried in nonsteady state condition for both tests, migration and diffusion coefficient, which were measured at 5,20 and $40^{\circ} \mathrm{C}\left(41,68\right.$ and $\left.104^{\circ} \mathrm{F}\right)$. They reported that activation energy of concrete measured from non-steady-state diffusion tests ranges from 17.9 to $39.9 \mathrm{~kJ} / \mathrm{mol}$, while the activation energy obtained from non-steady-state migration coefficient is around 20 $\mathrm{kJ} / \mathrm{mol}$ and independent of water to cement ratio. Yang and $\mathrm{Wang}^{33}$ addressed that the use of accelerated chloride migration test (ACMT) of unheated $\left(20^{\circ} \mathrm{C}\right)\left(68^{\circ} \mathrm{F}\right)$ and heated concrete $\left(95^{\circ} \mathrm{C}\right)\left(203^{\circ} \mathrm{F}\right)$ showed a significant increase of the chloride migration coefficients when concrete specimens are exposed from 20 to $95^{\circ} \mathrm{C}\left(68\right.$ to $\left.203^{\circ} \mathrm{F}\right)$ temperature. The breakthrough time had reduced at room temperature $\left(20^{\circ} \mathrm{C}\right)\left(68^{\circ} \mathrm{F}\right)$ to a limited range at $95^{\circ} \mathrm{C}$ $\left(203^{\circ} \mathrm{F}\right)$.

Otsuki et al. ${ }^{34}$ studied the influence of temperature on the mortar matrix paste specimens $(5 \times 5 \times 4 \mathrm{~mm})(0.19 \times 0.19 \times 0.15 \mathrm{in})$ from the central part of the cylindrical specimen of concrete 
$1(100 \times 200 \mathrm{~mm})(3.93 \times 7.87 \mathrm{in})$, the curing and the test diffusion was conducted under three

2 levels of temperature $\left(20,30\right.$ and $\left.40^{\circ} \mathrm{C}\right)\left(68,86\right.$ and $\left.104^{\circ} \mathrm{F}\right)$. The diffusion coefficient was

3 calculated using Fick's first law of diffusion. The activation energies obtained were from 70.4

4 to $134.9 \mathrm{~kJ} / \mathrm{mol}$.

5 Recently Doutsi and al. ${ }^{10}$ focused his work on the influence of exposure temperature ranging 6 from 22,35 to $50^{\circ} \mathrm{C}\left(71.6,95\right.$ to $\left.122^{\circ} \mathrm{F}\right)$ on chloride diffusion according to Fick's second law in control concrete and six different concrete mixtures containing various amounts of silica fume or natural zeolite. The results obtained by Dousti et al. ${ }^{10}$ have shown significant differences in diffusion coefficients between ordinary concrete and concrete mixtures from which the activation energies values were $31.9 \mathrm{~kJ} / \mathrm{mol}$ and less than $30.9 \mathrm{~kJ} / \mathrm{mol}$ respectively. Concerning modelling of chlorides penetration into concrete, there are many approaches in literature. However, when the temperature effect is considered, there are few models such as FIB model code $^{35}$ and Life-365 model $^{19}$. These models considered that the effect of temperature on chloride diffusion coefficient is in agreement with the Arrhenius law. The activation energy values proposed by such models are $40 \mathrm{~kJ} / \mathrm{mol}$ and $35 \mathrm{~kJ} / \mathrm{mol}$, regardless of concrete mixture type.

However, no report was found on studying the influence of coupling directly temperature with the coefficient of migration under an electric field in steady state in saturated concrete.

This work aims to characterize and analyze the effect of temperature upon the chloride diffusion under electric field of an ordinary and pozzolanic concrete, in saturated conditions; which leads to the objectives and research methodology adopted in this work.

In this study the temperatures selected were 5, 20, 30, 40 and $50^{\circ} \mathrm{C}(41,68,86,104$ and $\left.122^{\circ} \mathrm{F}\right)$, wich reflects the ranged typical ambient temperatures of the Mediterranean Sea. 
1 The durability is increasingly decisive for the design of reinforced concrete structures in a

2 saline environment. In such ambiance conditions, the temperature process is known to cause

3 faster penetration of chloride, and it's relevant for the service life design and reassessment of

4 reinforced concrete structures. The originality of the present work lies in the new test

5 experimental setup developed in order to apply a controlled range of temperature at same time

6 as the chloride migration occurs into saturated concrete conditions. The results presented in

\section{EXPERIMENTAL STUDY}

\section{Materials}

The binder used is a Portland cement composite CEM II/A 42.5 from the factory of Beni Saf, located in north-west Algeria, as specified in Standard NA $442^{36}$. It consists of $85 \%$ clinker, and $12 \%$ natural pozzolan and $3 \%$ gypsum. Its density is $3070 \mathrm{~kg} / \mathrm{m}^{3}\left(191.65 \mathrm{lb} / \mathrm{ft}^{3}\right)$ and Blaine specific surface area is $2705 \mathrm{~cm}^{2} / \mathrm{g}\left(1320.67 \mathrm{ft}^{2} / \mathrm{lb}\right)$. Its chemical composition is given in Table 1 and its mineralogical compositions is presented in Table 2.

The natural pozzolan used is extracted from the Bouhmidi deposit of pyroclastic rocky of volcanic origin located in Beni-saf (north-west of Algeria). It is generally accepted that the pozzolan sample is chemically suitable with a total content $\left(\mathrm{SiO}_{2}+\mathrm{Al}_{2} \mathrm{O}_{3}+\mathrm{Fe}_{2} \mathrm{O}_{3} \geq 70 \%\right)$ as mentioned in ACI report ${ }^{37}$, then satisfying the ASTM C $618^{38}$ requirements. And can be used to replace up to $40 \%$ of ordinary Portland cement in accordance with EN 197-1 and ASTM C $595^{39}$ standards. 
1 The natural pozzolan was dried at $105^{\circ} \mathrm{C}\left(221^{\circ} \mathrm{F}\right)$ and used as a powder resulting from a

2 grinding and clipping sieve of $80 \mu \mathrm{m}\left(0.00314\right.$ in). Its density is $2500 \mathrm{~kg} / \mathrm{m}^{3}\left(156.06 \mathrm{lb} / \mathrm{ft}^{3}\right)$ and Blaine specific surface area is $3360 \mathrm{~cm}^{2} / \mathrm{g}\left(1640.46 \mathrm{ft}^{2} / \mathrm{lb}\right)$, The chemical analysis of the resulting powder crushed at $80 \mu \mathrm{m}$ is reported in Table $\mathbf{1}^{40}$.

The size grading curve for the natural pozzolan was determined by laser granulometry. The average of three test shown that the diameter at $90 \%$ is $69 \mu \mathrm{m}\left(27.16 \times 10^{-4}\right.$ in), at $50 \%$ is 16 $\mu \mathrm{m}\left(6.299 \times 10^{-4}\right.$ in $)$ and at $10 \%$ is $2 \mu \mathrm{m}\left(0.787 \times 10^{-4}\right.$ in) (see Fig. 1).

The crushed aggregates used are limestone from the career of the National Company of Aggregates (ENG) located in west of Algeria. The maximum size of coarse aggregate is 25 $\mathrm{mm}(0.984 \mathrm{in})$ and their specific gravity is 2.58 . The maximum size, fineness modulus and specific gravity values of sand are respectively $4 \mathrm{~mm}(0.157 \mathrm{in}), 2.95 \%$ and 2.50 .

\section{Mixture proportions}

Two concretes designated OC and CPZ10 were used in this study. An ordinary concrete (OC) which many experimental data are available within our team ${ }^{41}$, was designed with binder content of $350 \mathrm{~kg} / \mathrm{m}^{3}\left(21.84 \mathrm{lb} / \mathrm{ft}^{3}\right)$ and water-binder ratio of 0.55 . Another concrete (CPZ10) containing pozzolanic substitution of $10 \%$ of the mass of cement was used to evaluate the effect of pozzolanic admixture on concrete proporties. The details of the concrete mixtures are summarized in Table 3.

\section{Sample Preparation}

In this test campaign, specimens were moulded in $11 \times 22 \mathrm{~cm}(4.33 \times 8.66$ in) PVC cylinders. After casting, they were demoulding after 24 hours and then immersed in water at $20^{\circ} \mathrm{C}$ $\left(68^{\circ} \mathrm{F}\right)$ for 28 days for each concrete in accordance with EN 206-1. At the end of the moist cure, these specimens were cut in order to extract three discs of $5 \mathrm{~cm}$ (1.96 in) thick, which 
are then sealed on their curved surface with epoxy resin to ensure a uniaxial flow inside the discs and rectified to have plane and cleaned surfaces. Then, they were dried at $105^{\circ} \mathrm{C}$ $\left(221^{\circ} \mathrm{F}\right)$ until reaching constant weight ${ }^{42}$; the middle disc was chosen and saturated ${ }^{43}$ to evaluate the water porosity and the effective chloride diffusion coefficient.

Chloride diffusion test

The assessment of diffusion coefficient take long time with natural diffusion test (minimum 9 month), Migration test were developed to accelerate the transport of chlorides ${ }^{20-21,44}$ and recently standardized as NF XP P18-461 45 according to the following principle : The disc of concrete was placed between the two compartments of a cell migration. A basic solution containing $\mathrm{NaOH}(0.025 \mathrm{M})$ and $\mathrm{KOH}(0.083 \mathrm{M})$ in the downstream compartment; the same solution laden with $\mathrm{NaCl}(0.513 \mathrm{M})$ in the upstream compartment. A $12 \mathrm{~V}$ potential difference was applied between the sides of the concrete sample. The downstream solution was sampled, and samples were titrated with silver nitrate $(0.05 \mathrm{M})$. As the flux became constant, the simplified Nernst-Planck relation ${ }^{20}$ allowed us to determine the value of the effective coefficient $\mathrm{D}_{\text {mig }}\left(\mathrm{m}^{2} / \mathrm{s}\right)\left(\mathrm{ft}^{2} / \mathrm{s}\right)$, as in Eq. (2):

$D_{m i g}=\left(\frac{R T L}{z F E C_{0}}\right) J$

Where $\mathrm{C}_{0}\left(\mathrm{~mol} / \mathrm{m}^{3}\right)\left(\mathrm{mol} / \mathrm{ft}^{3}\right)$ is the chloride concentration of the upstream compartment $(0,513), \mathrm{J}\left(\mathrm{mol} /\left(\mathrm{m}^{2} \mathrm{~s}\right)\right)\left(\mathrm{mol} / \mathrm{ft}^{2} \mathrm{~s}\right)$ is the flux of chloride ions, $\mathrm{z}(\mathrm{z}=1)$ is the chloride ion valency, $\mathrm{F}$ is the Faraday constant $(\mathrm{F}=96480 \mathrm{~J} /(\mathrm{V} \mathrm{mol})), \mathrm{E}(\mathrm{V})$ is the actual potential drop between the surfaces of specimen, $\mathrm{R}$ is the gas constant $(\mathrm{R}=8.3144 \mathrm{~J} /(\mathrm{mol} \mathrm{K}))(\mathrm{J} / \mathrm{mol} \mathrm{F}), \mathrm{T}(\mathrm{K})(\mathrm{F})$ is the absolute temperature, $\mathrm{L}(\mathrm{m})(\mathrm{ft})$ is the sample thickness. 
1 To undertake a study that takes into account the diffusion coupling with temperature, an

2 experimental device has been realized in EOLE laboratory (University of Tlemcen, Algeria).

3 This experimental apparatus is composed of a caulked water tank of capacity 15 liters (3.96 gal). A heater is disposed on the left side to generate heat and on the right side, a coil for the circulation of the refrigerant gas which is connected to the compressor and to the evaporator to generate cold. Both components are flooded in a liquid water mixed with rapeseed oil and are connected directly to the control panel by two thermostats respectively controlling the high and low temperatures. The apparatus is also equipped with a variable temperature that controlled hot and cold temperature (see Fig. 2).

A circular coil connected to the tank is installed around the disc of concrete for conditioning specimen at temperature fixed in advance; all pipes are protected by a caulking to prevent loss of temperature. The circulation of the coolant liquid is provided by a closed circuit provided with a peristaltic pump. The controlled temperature is maintained constant for at least four hours, so as to enable the latter to reach the heart of concrete disc. Finally, the migration under electric field is generated, once the temperature is uniform throughout all the sample of concrete.

One migration test was performed for each temperatures: $5,20,30,40$ and $50^{\circ} \mathrm{C}(41,68,86$, 104 and $\left.122^{\circ} \mathrm{F}\right)$. And for each temperature, a diffusion coefficient is obtained. The effect of temperature on the chloride diffusivity was taken into account, which was often expressed theoretically by Arrhenius law (Eq. 1). Hence, the relation of the chloride diffusion coefficients $\operatorname{Ln}(\mathrm{D}(\mathrm{T}))$ versus the inverse of the absolute temperature $(1 / T)$ is depicted. These data can be fitted by linear regression analysis to an unique straight line using the Arrhenius law . Then, the activation energy Ea is equal to the slope of the straight line $e^{10,29-31}$.

\section{Mercury intrusion porosimetry test (MIP)}


1 The mass transport in cement-based materials is largely controlled by the porosity, also

2 considered as a first durability index. Thus the porosity of cement-based materials and it's

3 microstructure are the main factors that affect the penetration of chlorides ${ }^{46-47}$.

4 For the characterization of porosity and pore size distribution of the studied materials, an

5 investigation by mercury intrusion porosimetry (MIP) measurements was conventionally

6 performed for its convenience and reliable results for all size of pores especially capillary

7 pores $^{48}$. Moreover, the MIP provides information on the threshold pore size which is considered relevant for the assessment of the resistance to transport of substance in the

9 material $^{49}$.

For this test campaign, two cubic samples of each mixtures having dimensions of $1.5 \times 1.5 \times 2$ $\mathrm{cm}^{3}\left(0.59 \times 0.59 \times 0.78 \mathrm{in}^{3}\right)$ cut from cylindrical disc $\varnothing 110 \times 50 \mathrm{~mm}(\varnothing 4.33 \times 1.96$ in $)$ specimens were prepared and dried by putting them in an oven at $\mathrm{T}=40^{\circ} \mathrm{C}\left(104^{\circ} \mathrm{F}\right)$ until reached a constant weight and stored in sealed containers for the MIP test. The MIP test was carried out on a Micromeritics AutoPore-9500 mercury intrusion porosimeter capable of generating pressure in the range of subambient to $414 \mathrm{MPa}^{50}$ (60000 psia).

\section{RESULTS AND DISCUSSION}

The accumulation of chloride ions in the downstream compartment is shown as a function of time for OC and CPZ10 in Figure 3 for different exposure temperatures.

From the results obtained in this study, summarized in Fig. 3 and Table 4, the results emphasize the effect of the type of concrete on diffusion coefficients. The chloride migration coefficients calculated at the temperature level for the mixture concrete containing pozzolan is lower than the migration coefficient of chloride through the ordinary concrete. Intuitively, a lower effective chloride diffusion coefficient value is expected to increase the time to corrosion initiation, consequently service life of the structure. For all temperature range 5 to 
$50^{\circ} \mathrm{C}$ (41 to $122^{\circ} \mathrm{F}$ ), the use of $10 \%$ pozzolan reduce the $\mathrm{CPZ10}$ migration coefficient by about $32 \%$ compared with OC migration coefficient. This result is in agreement with other researchers who have studied concrete with pozzolanic additions ${ }^{10,28,}$.

Moreover, the water porosity of OC concrete is higher than the porosity of CPZ10 concrete (15.08\% vs. 13.79\%), as presented in Table 3. As shown by Fig. 4, the pore structure of the two kinds of specimen's concrete is characterized by MIP and presents the pore size distribution at the age of 90 days. The discussed results below are the average of two tests per sample concrete. It can be noticed that the cumulative volume of pores for OC $(0.0493 \mathrm{ml} / \mathrm{g})$ (0.75615 fl.oz/lb) showed high values than CPZ10 $(0.0393 \mathrm{ml} / \mathrm{g})(0.60277 \mathrm{fl} . \mathrm{oz} / \mathrm{lb})$, thus the volume of pores is reduced by about $20 \%$; and the critical pore diameter which corresponds to the maximum of porosity given by the pore size distribution of CPZ10 report a distinctly different pore size diameter relative to $\mathrm{OC}(0.0935$ vs. $0.0481 \mu \mathrm{m})(0.03681 \mathrm{x} 10-4$ vs. $0.01893 \times 10-4$ in) but still remaining in the range of meso-pores. The reason for these differences in the main peak and the cumulative pore volume of concrete CPZ10 compared to OC is related to two effects, first the total volume of capillary is reduced, and second there is a shift of the curve to the left characterizing the reduction of capillary-sized pores which is explained by the refinement of the porosity due to lower amounts of pore inter-gel particles and macro-pores due to the substitution in mass content in cement by pozzolanic addition ${ }^{47}$. Indeed, the substitution of $10 \%$ mass content in cement by pozzolan reacts with portlandite outcome from cement hydration and form additional calcium silicate hydrates which are filling the voids and thus reduce the interlayer interconnectivity of the pores ${ }^{51}$. Therefore, the results show that mercury porosity of CPZ10 (9.85\%) is less than OC porosiy $(11.39 \%)$ (see Table3): the decrease of porosity is in accordance with the reduction of water porosity. The pozzolanic substitution induces a more compact microstructure and a lower pore connectivity. The concrete sustainability performance is improved by substituted Portland cement by 
2 to environmental conditions and the mass transport is slower in these concretes ${ }^{40,52}$. As

pozzolanic admixture. Indeed, the lowest porous concretes (with pozzolan) are less sensitive results, the size of paths of chloride penetration is modified and the transport mode occurring causes a decrease in coefficient of migration of CPZ10 than OC. This is in accordance with many researchers which have proposed various relationships between diffusion chlorides and the microstructure of cement based materials such as its evolution of pore structure ${ }^{43,53-54}$. Otherwise, by examining the results of migration test for all temperature, it is clear that the $\mathrm{Cl}^{-}$ diffusivity of both concretes increased with the temperature rising.

Additionally, the time lag $\mathrm{T}_{\text {lag }}$ varies with the diffusion coefficient. It was shown that for $\mathrm{T}_{\mathrm{lag}}$ of CPZ10 is higher than for OC for the same temperature as shown in Table 4. Firstly, a higher $\mathrm{T}_{\text {lag }}$ may result from a lower porosity, this is an effect of the material composition that $\mathrm{T}_{\text {lag }}$ depends on the porosity of concrete as cited in some research ${ }^{55-58}$. Secondly, if we focus on variation of temperature for the two concretes taken separately, increasing of temperature of 5 to $50^{\circ} \mathrm{C}$ ( 41 to $122^{\circ} \mathrm{F}$ ), has two effect: one, to release of ions binding and to increase the concentration of free chlorides in the pores and second, catalytic effect of temperature on diffusion speed, then allows to chlorides to accelerate and reach the downstream part of the material more rapidly as confirmed by researchers ${ }^{31,59}$. This phenomenon is more marked for OC than the CPZ10 because the increase of porosity and amount of binding chlorides is lower which results a great chloride diffusion coefficient evidenced by the significant decrease in delay time $\mathrm{T}_{\text {lag }}$ registered.

Furthermore, as shown the experimental results in Fig. 5. It can be concluded that there is a regression relation between the diffusion coefficient and the delay time as mentioned by Djerbi et al. ${ }^{44}$. This variation is depending on the temperature and it is specific for each type of concrete. From these results, a major conclusion leads us to think that the important time lag recorded for low temperature $5^{\circ} \mathrm{C}\left(41^{\circ} \mathrm{F}\right)$ for both concrete CPZ10 (124 h) and OC (92 h) 
are due to slowly kinetics chlorides penetration, characterized by small diffusion coefficients. On the other hand, at temperatures above than $30^{\circ} \mathrm{C}\left(86^{\circ} \mathrm{F}\right)$ the free ions in solution pores become increasingly more constant amount and are conditioning by the porosity of the material, then the diffusion is less dependent on chlorides interactions but rather, it is activated in fact in terms of the speed diffusion by increasing the temperature, it is very clear that delay times are close, and varying respectively around $12 \%$ for $\mathrm{CPZ}$ and $21 \%$ for OC passing from 30 to $50^{\circ} \mathrm{C}$ ( 86 to $122^{\circ} \mathrm{F}$ ), with the increase of the diffusion coefficient. Probably delay time can still evolve, that if the microstructure is modified by a higher temperature (to beyond $\left.80^{\circ} \mathrm{C}\left(176^{\circ} \mathrm{F}\right)\right)^{60}$ or a mechanical damage $e^{43-44,57}$, resulting in greater porosity making penetration most important. it must be examined whether will there be shifts on time delay for the high temperatures.

Fig. 6, presents the evolution of migration coefficient as a function of temperature. The results show that the relationship diffusion - temperature increases regularly. Indeed, we mentioned that the coefficient of migration increases with increasing temperature from 5 to $50^{\circ} \mathrm{C}$ (41 to $\left.122^{\circ} \mathrm{F}\right)$. This is because the cumulative concentration of chlorides characterized with a diffusion coefficient respectively for CPZ10 and OC, in one hand, decreases by 58 and 60\% with lowering the temperature from 20 to $5^{\circ} \mathrm{C}\left(68\right.$ to $\left.41^{\circ} \mathrm{F}\right)$, in other hand, an increase of 64 and $66 \%$ of diffusion coefficient with increasing temperature from 20 to $50^{\circ} \mathrm{C}$ (68 to $122^{\circ} \mathrm{F}$ ). in other words, we can see that a penetration kinetics of chlorides is lower at low temperatures $\left(5^{\circ} \mathrm{C}\right)\left(41^{\circ} \mathrm{F}\right)$ resulted with an effective diffusion coefficient $\left(\mathrm{D}_{\mathrm{mig}}\right)$ of more than about two times lower in an ambient temperature of $20^{\circ} \mathrm{C}\left(68^{\circ} \mathrm{F}\right)$, and a penetration rate of chlorides with higher temperature $\left(50^{\circ} \mathrm{C}\right)\left(122^{\circ} \mathrm{F}\right)$, has led to about three times diffusion coefficient in relation to a temperature of $20^{\circ} \mathrm{C}\left(68^{\circ} \mathrm{F}\right)$. It is worth to mention that the increase of diffusion coefficient with the temperature level for each concrete investigated is consistent with some works without taking reference to the methods used by these authors ${ }^{10,25,26,32-34}$. 
1 In fact, at the temperature of $5^{\circ} \mathrm{C}\left(41^{\circ} \mathrm{F}\right)$, the coefficient of diffusion is lower for both

2 concrete, because ionic diffusion and chemical reaction are showed down; this finding is in

3 accordance with some works ${ }^{32,61}$.

4 In the case of temperature 20 and $30^{\circ} \mathrm{C}\left(68\right.$ and $\left.86^{\circ} \mathrm{F}\right)$ experimentally, the both concrete

5 diffusion behaved slightly evolution in terms of chloride diffusivity registered; that display

6 limited to a relative variation of $23 \%$.

7 However, we can also observe that the effect of the increase in temperature causes a large coefficient in the temperature range from 30 to $50^{\circ} \mathrm{C}\left(86\right.$ to $\left.122^{\circ} \mathrm{F}\right)$ then the average variation is about $33 \%$ for a gap of $10^{\circ} \mathrm{C}\left(50^{\circ} \mathrm{F}\right)$. As a consequence, the effect of the speed level of chloride penetration is due to the impact of the temperature level on the diffusion coefficient in the temperature range above $30^{\circ} \mathrm{C}\left(86^{\circ} \mathrm{F}\right)$. This was evidenced by a bi-linear trend (see Fig. 6), which is more representative of the evolution of diffusion temperature.

In fact, the diffusion coefficient values tend to increase with temperature; that means the temperature modify significantly the diffusion coefficient. Such evolution can be expected to have a substantial impact on the service life of reinforced concrete in chloride environments. Therefore, structures exposed to hot climates will potentially deteriorate more rapidly due to increased transport and chemical reaction rates. This observation is in accordance with other work on slightly different materials ${ }^{10,32,61}$.

Of this, it's more important to take role of temperature on ionic transport in cementitious materials, in order not to underestimate the life of structures.

Furthermore, the $\mathrm{D}_{\text {mig }}$ of concrete can be estimate based on the energy calculated by the Arrhenius equation at different temperatures. The relationship of the logarithm $\operatorname{Ln}\left(\mathrm{D}_{\mathrm{mig}}\right)$ as a function of the reciprocal of the absolute temperature is shown in Fig. 7.

From these Figure, the adjustment of the curve made by linear regression analysis of the Arrhenius equation, leads us to estimate by means of the slope of this line the value of the 
activation energy which is respectively about $32.45 \mathrm{~kJ} / \mathrm{mol}$ for $\mathrm{OC}$ and $30.02 \mathrm{~kJ} / \mathrm{mol}$ for CPZ10 (see Fig. 7). The correlation coefficients for the lines obtained for OC and CPZ10 were calculated to be 0.98 . Therefore, it can be concluded that the diffusion of $\mathrm{Cl}^{-}$in concrete follows the Arrhenius theory and it can be noted that logarithms of the diffusivity of chloride in concrete, were linearly proportional to the reciprocal of absolute temperature.

The result of activation energy obtained is close to those obtained by some authors ${ }^{10,26,28,30}$ cited, a value that fluctuates between 17.9 and $40 \mathrm{~kJ} / \mathrm{mol}$ for cement, mortar and concrete materials.

We mention that the activation energies obtained from cement paste might be different from those obtained from concrete. Thus, we will compare our activation energies values with those obtained by Dousti et al. ${ }^{10}$, including control concrete $(\mathrm{Ea}=29.40 \mathrm{~kJ} / \mathrm{mol})$ and concrete mixture incorporating $10 \%$ of the natural zeolite $(\mathrm{Ea}=28.88 \mathrm{~kJ} / \mathrm{mol})$, which seems close natural pozzolan used in this study ${ }^{56}$. Then, it seems that the values obtained for the two kinds of concretes are relatively close. This fact indicates that the kinetics chloride diffisuvity in concrete apparently agrees with the Arrhenius theory. At the end, from experimental results, the activation energy calculated can be used into Eq. (1) to estimate diffusion coefficients at different temperatures. Fig. 8 shows the comparison between the experimentally data obtained and the calculated values. Then, we conclude that exists a good agreement as confirmed by Dousti et al. ${ }^{10}$.

The objective of this study was to evaluate the influence of pozzolanic substitution and the effect of temperature on the effective diffusion coefficient of chloride in the concretes. The main conclusions of the present study are: 
1 1. The characterization by MIP measurements of concrete for substitution of part of the cement mass proportion $(10 \%)$ of the pozzolan showed a significant reduction in the porosity of the CPZ10 concrete than OC concrete. This was explained by the reduction of the pores volume and the critical diameter, which leads a microstructure more compact; whole largely conditioning the transport mechanisms in the concrete. In terms of sustainability, it is systematically confirmed by recording a reduction of diffusion coefficients.

2. The presence of pozzolan in the cement used as mass substitution (10\%) can significantly reduce porosity and effective diffusion coefficient of concrete studied for all temperatures range.

3. The temperature level has an impact on the kinetics of penetration of chlorides. Then, it always recording an increase of the effective diffusion coefficient of both concrete OC and CPZ10 studied when the temperature rising. There is a decreasing regression between coefficient diffusion and time lag. Thus, the time lag $\left(\mathrm{T}_{\mathrm{lag}}\right)$ was almost decreasing and the influence of temperature is well related to the weakness of binding chloride which becomes minimal above $30^{\circ} \mathrm{C}\left(86^{\circ} \mathrm{F}\right)$ as confirmed by an increase of diffusion coefficient du the speed diffusion and close time lag.

4. The activation energy calculated from the Arrhenius equation remains close to that presented in the literature.

5. Finally, it can be seen that the relationship between the logarithms of diffusion coefficient and reciprocal of absolute temperature are linearly distributed. Therefore, it can be concluded that the behaviour of diffusion $\mathrm{Cl}$ - in concrete follows the Arrhenius theory. Also, a good agreement was found between the experimental data and the Arrhenius theory. 
1 The authors would like to acknowledge the financial support of TASSILI project

2 (10MDU811) on durability and aging of concrete materials, maintenance and reliability of

3 structures on the coast, whose funding allowed for this work. Our thanks go also to GeM

$4 \quad$ Laboratory (France) and EOLE Laboratory (Algeria) for their support.

5

\section{REFERENCES}

1. Verbeck, G. J., "Mechanisms of corrosion in concrete," in 'Corrosion of Metals in Concrete', SP-49, American Concrete Institute, 1975, pp. 21-38.

2. Hassain, S. E., Al-Gahtani, A. S., Rasheeduzzafar, "Chloride threshold for corrosion of reinforcement in concrete,” ACI Materials Journal, V. 93, No. 6, 1996, pp. 1-5.

3. Kondraivendhan, B., and Bhattacharjee B. Effect of age and water-cement ratio on size and dispersion of pores in ordinary portland cement paste," ACI Materials Journal, V. 107, No. 2, 2010, pp. 147-154.

4. Ellis, W. E. Jr., Rigg, E. H. and Butler, W. B., "Comparative results of utilization of fly ash, silica fume and GGBFS in reducing the chloride permeability of concrete," in 'Durability of Concrete', SP-126, American Concrete Institute, Detroit, MI, 1991, pp. 443-458.

5. Mehta, P. K., "Role of pozzolanic and cementitious material in sustainable development of concrete industry," In: Malhotra VM, editor. Proceedings of the sixth CANMET/ACI/JCI, international conference on fly ash, silica fume and natural Pozzolans in concrete, American Concrete Institute, Michigan, ACI SP-178, V. 1, 1998, p. 1-20.

6. Collepardi, S., Corinaldesi, V., Moriconi, G., Bonora, G. and Collepardi, M., "Durability of high-performance concretes with pozzolanic and composite cements," ACI special report SP 192-10, American Concrete Institute, 2000. 
1 7. Das, B. B., and Kondraivendhan, B., "Implication of pore size distribution parameters on

2 compressive strength, permeability and hydraulic diffusivity of concrete," Construction and 3 Building Materials, V. 28, No. 1, 2012, pp. 382-386.

4 8. Hu, Y. J., and Du, Y. L., "Effect of Pore Structure on the Chloride Permeability of 5 Concrete with Mineral Admixture," Advanced Materials Research, V. 690-693, 2013, pp. $6 \quad 835-838$.

7 9. Dhir, R. K., Jones, M. R., and Elghaly, A.E., "PFA concrete: exposure temperature effects on chloride diffusion," Cement and Concrete Research., V. 23, No. 5, 1993, pp. 1105-1114. 10. Dousti, A., Rashetnia, R., Ahmadi, B., and Shekarchi, M., "Influence of exposure temperature on chloride diffusion in concretes incorporating silica fume or natural zeolite," Construction and Building Materials, V. 49, 2013, pp. 393-399.

11. Alexander, M., Bertron, A., and Belie, N. D., "Performance of cement-Based materials in aggressive aqueous environments," Eds RILEM TC211-PAE, state of the art reports 10, chap.13, Springer, 2013, pp. 319-343.

12. Alfarabi, S., Loughlin, K. F., Azad, A. K., and Navaz, C. M., "Determination of the Effective Chloride Diffusion Coefficient in Concrete via a Gas Diffusion Technique," ACI Materials Journal, V. 94, No. 3, 1997, pp. 227-233.

13. Castellote, M., Andrade, C., and Alonso, C., "Measurement of the steady and nonsteady state chloride diffusion coefficients in a migration test by means of monitoring the conductivity in the anolyte chamber - Comparison with natural diffusion tests," Cement and Concrete Research, V. 31, No. 10, 2001, pp. 1411-1420.

14. Stephen, L. D., Detwiler, R. J., and Hooton R. D., “Testing Transport Properties of Concrete," ACI Journal Concrete International, V. 32, No. 11, 2010, pp. 33-38 
15. ASTM C1202-05, "Standard Test Method for Electrical Indication of Chloride's Ability to Resist Chloride," Annual Book of ASTM Standards, V. 04.02, ASTM international, West Conshohocken, PA, 2005.

16. ASTM C1556, Determining the apparent Chloride Diffusion Coefficient of Cementitious Mixtures by Bulk Diffusion,” ASTM Standards, ASTM International, West Conshohocken, PA, 2011.

17. Maage, M., Helland, S., Poulsen, E., Vennesland, Ø., and Carlsen, J. E., "Service life prediction of existing concrete structures exposed to marine environment," ACI Materials Journal, V. 93, No. 6, 1996, pp. 602-608.

18. Luciano, J., and Miltenberger, M., "Predicting chloride diffusion coefficients from concrete mixture proportions," ACI Materials Journal, V. 96, No. 6, 1999, pp. 698-702.

19. Thomas, M. D. A., and Bentz, E. C., "Life 365: computer program for predicting the service life and life-cycle costs of reinforced concrete exposed to chlorides," In: ACI, Committee 365, Service Life Prediction, Detroit, Michigan; 2001.

20. Andrade, C., "Calculation of chloride diffusion coefficient in concrete from ionique diffusion measurements," Cement and Concrete Research, V. 23, No. 3, 1993, pp. 724-742.

21. Truc, O., "A new way for determining the chloride diffusion coefficient in concrete from steady state diffusion test," Cement and Concrete Research, V. 30, No. 2, 2000, pp. 217-226.

22. Luping, T., and Nilsson, L., "A rapid determination of chloride diffusivity in concrete by applying an electrical field," ACI Materials Journal, V. 89, No. 1, 1992, pp 49-53.

23. Tong, L., and GjØrv, O.E., "Chloride diffusivity based on migration testing," Cement and Concrete Research, V. 31, No. 7, 2001, pp. 973-982.

24. Detwiler, R. J., Kjellsen, K. O., and Gjorv, O.E. "Resistance to Chloride Intrusion of Concrete Cured at Different Temperatures," ACI Materials Journal, V. 88, No. 1, 1991, pp. $19-24$. 
25. Al-Khaja, W. A., "Influence of temperature, cement type and level of concrete consolidation on chloride ingress in conventional and high-strength concretes," Construction and Building Materials, V. 11, No. 1, 1997, pp. 9-13.

26. Yuan, Q., Shi, C., Schutter, G. D., and Audenaert, K., "Effect of temperature on transport of chloride ions in concrete,” In: Alexander, M. G., Beushausen, H. D., Dehn, F., and Moyo, P., Editors. Proceedings of the $2^{\text {nd }}$ International conference on concrete repair, rehabilitation and retrofitting, Cape Town, 2008, pp. 345-51.

27. Panesar, D. K., and Chidiac, S. E., "Effect of cold temperature on the chloride-binding capacity of cement," Journal of Cold Regions Engineering V. 25, No. 4, 2011, pp. 133-144. 28. Collepardi, M., Marcialis, A., and Turriziani, R., "Penetration of chloride ions into cement pastes and concretes," Journal of the American Ceramic Society, V. 55, No. 5, 1972, pp. 534535.

29. Goto, S., and Roy, D. M., "Diffusion of ions through hardened cement pastes," Cement and Concrete Research, V. 11, No. 5-6, 1981, pp. 751-757.

30. Page, C. L., Short, N. R., and Tarras, A. E. I., "Diffusion of chloride ions in hardened cement pastes," Cement and Concrete Research, V. 11, No. 3, 1981, pp. 395-406.

31. Nguyen, T.S., Lorente, S., and Carcasses, M., "Effect of the environment temperature on the chloride diffusion through CEM-I and CEM-V mortars: an experimental study," Construction and Building Materials, V. 32, No. 2, 2009, pp. 795-803.

32. Samson, E., and Marchand, J., "Modeling the effect of temperature on ionic transport in cementitious materials," Cement and Concrete Research, V. 37, No. 3, 2007, pp. 455-468.

33. Yang, C. C., and Weng, S. H., "Effect of $95^{\circ} \mathrm{C}$ temperature on the chloride-migration of concrete using electrical field," Materials Chemistry and Physics, V. 125, No. 3, 2011, pp. 876-882. 
1 34. Otsuki, N., Madlangbayan, M. S., Nishida, T., Saito, T., and Baccay, M. A., "Temperature

2 dependency of chloride induced corrosion in concrete," Journal of Advanced Concrete

3 Technology, V. 7, No. 1, 2009, pp. 41-50.

4 35. Beton Fib, "Model code for service life design," Model code, FIB-Fed, Int du Beton,

5 CEB-FIP, Bulletin 34, Lausanne, Switzerland, 2006.

6 36. NA 442, "Cement: Composition, specifications and conformity criteria for common 7 cements," Algerian Standard, Algeria, 2005.

37. ACI 232.1R-00, "Use of Raw or Processed Natural Pozzolans in Concrete," ACI

Committee 232, Manual of Concrete Practice ACI 232.1R-00; ACI, Farmington Hills, MI 2000.

38. ASTM C618-12a, "Standard specification for coal fly ash and raw or calcined natural pozzolan for use in concrete," American Society for Testing and Materials, West Conshohocken, PA, 2012.

39. ASTM C595, "Standard Specification for Blended Hydraulic Cements,” American Society for Testing and Materials, West Conshohocken, PA, 2003.

40. Kaid, N., Cyr, M., Julien, S., and Khelafi, H., "Durability of concrete containing a natural pozzolan as defined by a performance-based approach," Con. Buil. Mat. V. 23, No. 12, 2009, pp. 3457-3467.

41. Boukli, S. M. A., “Contribution à l'étude de la résistance caractéristique des bétons de la région de Tlemcen," PhD thesis, University of Tlemcen, Algeria, 2009, p. 234.(in French). 42. AFPC-AFREM. "Durabilité des bétons : Méthode recommandée pour la mesure des grandeurs associées à la durabilité,” Report of Technical Journeys AFPC-AFREM, Toulouse, France, 1997, p. 283. (in French). 
1 43. Ben Fraj A., Bonnet S., Khelidj A., "New approach for coupled chloride/moisture

2 transport in non-saturated concrete with and without slag," Construction and Building

3 Materials, V. 35, 2012, pp. 761-771.

4 44. Djerbi, A., Bonnet, S., Khelidj, A., and Baroghel-bouny, V., "Influence of traversing

5 crack on chloride diffusion into concrete," Cement and Concrete Research, V. 38, No. 6, $6 \quad$ 2008, pp. 877-883.

7 45. NF XP P18-461, "Essai sur béton durci : Essai accéléré des ions chlorure en régime 8 stationnaire, détermination du coefficient de diffusion effectif des ions chlorure," French 9 Standard, France, 2012. (in French).

46. Mehta, P. K., and Monteiro, P. J. M., "Concrete: Microstructure, Properties and Materials,” 3rd Edition, the McGraw-Hill Companies, Inc.: New York, NY, USA, 2005.

47. Michael Thomas, "Supplementary cementing materials," CRC Press Taylor \& Francis Group, FL 33487-2742 Boca Raton, NW, USA, 2013.

48. Kumar, R., and Bhattacharjee, B., "Study on some factors affecting the results in the use of MIP method in concrete research," Cement and Concrete Research, V. 33, No. 3, 2003, pp. $417-424$.

49. Li, L.Y., "A pore size distribution-based chloride transport model in concrete," Magazine of Concrete Research, V. 66, No. 18, 2014, pp. 937-947.

50. AutoPore IV 9500, “Operator's Manual V1.04 Appendix D,” Micromeritics Instrument corporation, USA, 2001.

51. Khan, M. I., and Alhozaimy, A. M., "Properties of natural pozzolan and its potential utilization in environmental friendly concrete," Canadian Journal of Civil Engineering, V. 38, No. 1, 2011, pp. 71-78. 
1 52. Touil, B., Ghomari, F., Bezzar, A., Khelidj, A., and Bonnet, S., "Les bétons aux

2 pouzzolanes en façade maritime," Proceedings 1O-270, CMSS2013, Rabat, Maroc, 2013, p.

3 100. (in French).

4 53. Yang, C. C., "On the relationship between pore structure and chloride diffusivity from

5 accelerated chloride migration test in cement-based materials," Cement and Concrete 6 Research, V. 36, No. 7, 2006, pp. 1304-1311.

7 54. Sun, G. W., Sun, W., Zhang, Y. S., and Liu, Z. Y., "Relationship between chloride diffusivity and pore structure of hardened cement paste," Journal of Zhejiang UniversityScience A (Applied Physics \& Engineering), V. 12, No.5, 2011, pp. 360-367.

55. Coussy, O., and Eymard, R., "Non-linear binding and the diffusion-migration test," Transport in Porous Media, V. 53, 2003, pp. 51-74.

56. Touil, B., Ghomari, F., Bezzar, A.; Khelidj, A., and Bonnet, S., "Effect of natural pozzolan on concrete's durability,” ICDS12, Lisboa, Portugal, 31 May - 1 June, 2012, p. 8.

57. Djerbi, A., Bonnet, S., Khelidj, A., and Baroghel-bouny, V., "Effect of uniaxial compressive loading on gas permeability and chloride diffusion coefficient of concrete and their relationship," Cement and Concrete Research, V. 52, 2013, pp. 131-139.

58. Touil, B., Ghomari, F., Bezzar, A., Khelidj, A. and Bonnet, S., "Etude des performances de durabilité des bétons locaux," Proceedings 29th Meeting of AUGC, Civil engineering at the service of the Mediterranean, Tlemcen, Algeria, 29-31 May 2011, V. 2, pp. 53-64. (in French).

59. Jensen, O. M., Korzen, M. S. H., Jakobsen, H. J., Skibsted, J., "Influence of cement constitution and temperature on chloride binding in cement paste," Advances in Cement Research, V. 12, No. 2, 2000, pp. 57-64.

60. Caré S., "Effect of temperature on porosity and on chloride diffusion in cement pastes," 
1 61. Lin, S.H., "Chloride diffusion in porous concrete under conditions of variable

2 temperature," Wärme - und Stoffübertragung, Springer Link, V. 28, No. 7, 1993, pp. 411-415.

3

4

5

\section{TABLES AND FIGURES}

\section{List of Tables:}

Table 1 - Chemical compositions of cement and pozzolan (\%).

Table 2 - Mineralogical (Bogue) compositions of cement.

Table 3 - Mixture proportions and physical properties.

Table 4 - Coefficients of diffusion at different temperatures.

\section{List of Figures:}

Fig. 1 - Laser granulometry of Cement and Natural pozzolan.

Fig. 2 - Migration cell with hot and cold device.

Fig. 3 - Evolution cumulative increase of chloride concentration in downstream cell of OC and CPZ10 at different temperatures.

Fig. 4 - Measured porosity in OC and CPZ10 specimens using MIP test.

Fig. 5 - Relationship between the time lag and the diffusion coefficient of function of the different temperatures.

Fig. 6 - Chloride diffusion coefficient as a function of temperature.

Fig. 7 - Arrhenius plots of the diffusivity in concrete mixtures.

Fig. 8 - Comparison between the experimentally obtained and calculated diffusion coefficients.

\section{Table 1-Chemical compositions of cement and pozzolan (\%)}

\begin{tabular}{ccc}
\hline & CEM II/A 42.5 & Pozzolan \\
\hline \hline $\mathrm{SiO}_{2}$ & 27.95 & 46.8 \\
\hline
\end{tabular}




\begin{tabular}{ccc}
\hline \hline $\mathrm{Al}_{2} \mathrm{O}_{3}$ & 5.43 & 18.8 \\
\hline $\mathrm{Fe}_{2} \mathrm{O}_{3}$ & 3.05 & 10.5 \\
\hline $\mathrm{CaO}$ & 56.37 & 9.2 \\
\hline $\mathrm{MgO}$ & 0.71 & 3.8 \\
\hline $\mathrm{SO}_{3}$ & 2.53 & 0.2 \\
\hline $\mathrm{Na}_{2} \mathrm{O}$ & 0.30 & 0.8 \\
\hline $\mathrm{K}_{2} \mathrm{O}$ & 0.43 & 0.5 \\
\hline $\mathrm{CaO}_{\text {Free }}$ & 0.75 & - \\
\hline Loss of ignition & 3.11 & 6.5 \\
\hline \hline
\end{tabular}

1

\begin{tabular}{ccccccc}
\hline $\begin{array}{c}\text { Temp. } \\
{ }^{\circ} \mathrm{C}\left({ }^{\circ} \mathrm{F}\right)\end{array}$ & $\begin{array}{c}\text { Coefficients of diffusion } \\
\mathrm{D}_{\text {mig }} \mathrm{m}^{2} / \mathrm{s} . \mathrm{E}^{-12}\left(\mathrm{ft}^{2} / \mathrm{s}\right)\end{array}$ & $\begin{array}{c}\text { Lag time (Hours) } \\
\mathrm{T}_{\mathrm{lag}}\end{array}$ & $\begin{array}{c}\text { Activation Energy } \\
\text { Ea }(\mathrm{kJ} / \mathrm{mol})\end{array}$ \\
\hline \hline $5(41)$ & $\mathrm{OC}$ & $\mathrm{CPZ10}$ & $\mathrm{OC}$ & $\mathrm{CPZ10}$ & $\mathrm{OC}$ & $\mathrm{CPZ10}$ \\
\hline $2.03(21.85)$ & $1.49(16.03)$ & 92.51 & 124.04 & & \\
$30(68)$ & $5.13(55.21)$ & $3.56(38.31)$ & 54.84 & 57.51 & & 30.02 \\
$40(104)$ & $6.71(72.22)$ & $4.52(48.65)$ & 47.04 & 56.73 & 32.45 & \\
$50(122)$ & $10.10(108.71)$ & $6.34(68.24)$ & 44.18 & 51.61 & & \\
\hline \hline
\end{tabular}

Table 3-Mixture proportions and physical properties

\begin{tabular}{lcc}
\hline \hline \multicolumn{1}{c}{ Mix ingredients } & OC & CPZ10 \\
\hline \hline Coarse aggregate, $\left(\mathrm{kg} / \mathrm{m}^{3}\right)\left(\mathrm{lb} / \mathrm{ft}^{3}\right)$ & $1109(69.23)$ & $1109(69.23)$ \\
\hline Sand, $\left(\mathrm{kg} / \mathrm{m}^{3}\right)\left(\mathrm{lb} / \mathrm{ft}^{3}\right)$ & $660(41.20)$ & $660(41.20)$ \\
\hline Cement CPA-CEM II/A $42.5\left(\mathrm{~kg} / \mathrm{m}^{3}\right)\left(\mathrm{lb} / \mathrm{ft}^{3}\right)$ & $350(21.84)$ & $315(21.84)$ \\
\hline Pozzolan $\left(\mathrm{kg} / \mathrm{m}^{3}\right)\left(\mathrm{lb} / \mathrm{ft}^{3}\right)$ & - & $35(2.18)$ \\
\hline w/b $(\%)$ & 0.55 & 0.55 \\
\hline Slump $(\mathrm{cm})($ in) & $8(3.14)$ & $7(2.75)$ \\
\hline Compressive strength at 28 days $(\mathrm{MPa})(\mathrm{psi})$ & $34.10(4945.78)$ & $32.50(4713.72)$ \\
\hline Compressive strength at 90 days $(\mathrm{MPa})(\mathrm{psi})$ & $37.80(5482.42)$ & $40.20(5830.51)$ \\
\hline Water porosity $(\%)$ & 15.08 & 9.85 \\
\hline Mercury porosity $(\%)$ & 11.39 & 11.39 \\
\hline \hline
\end{tabular}

Table 4-Coefficients of diffusion at different temperatures.

Table 2-Mineralogical (Bogue) compositions of cement

\begin{tabular}{cc}
\hline \hline & Bogue composition (\%) \\
\hline \hline $\mathrm{C}_{3} \mathrm{~S}$ & 55.65 \\
\hline $\mathrm{C}_{2} \mathrm{~S}$ & 20.18 \\
\hline $\mathrm{C}_{3} \mathrm{~A}$ & 9.77 \\
\hline $\mathrm{C}_{4} \mathrm{AF}$ & 9.5 \\
\hline Gypsum & 3 \\
\hline
\end{tabular}




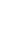

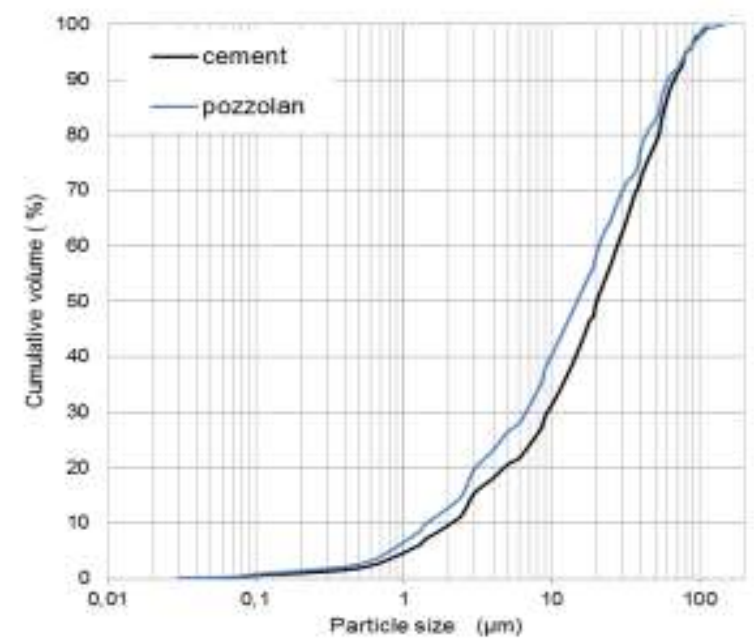

Fig. 1- Laser granulometry of Cement and Natural pozzolan (Note : $1 \mu \mathrm{m}=3.93710^{-5}$ in.) .

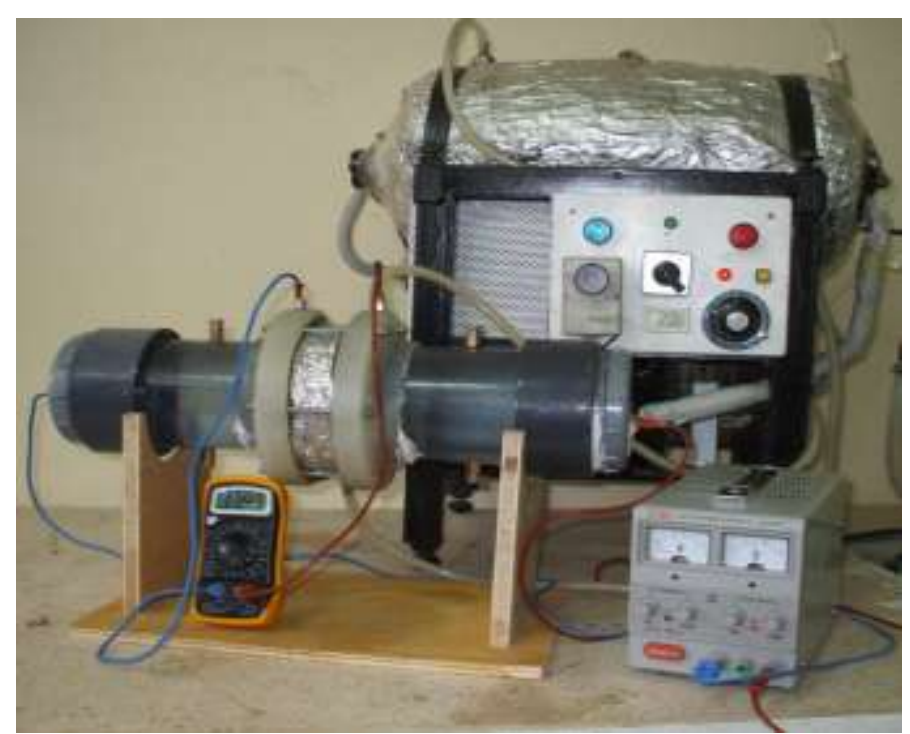

Fig. 2-Migration cell with hot and cold device. 


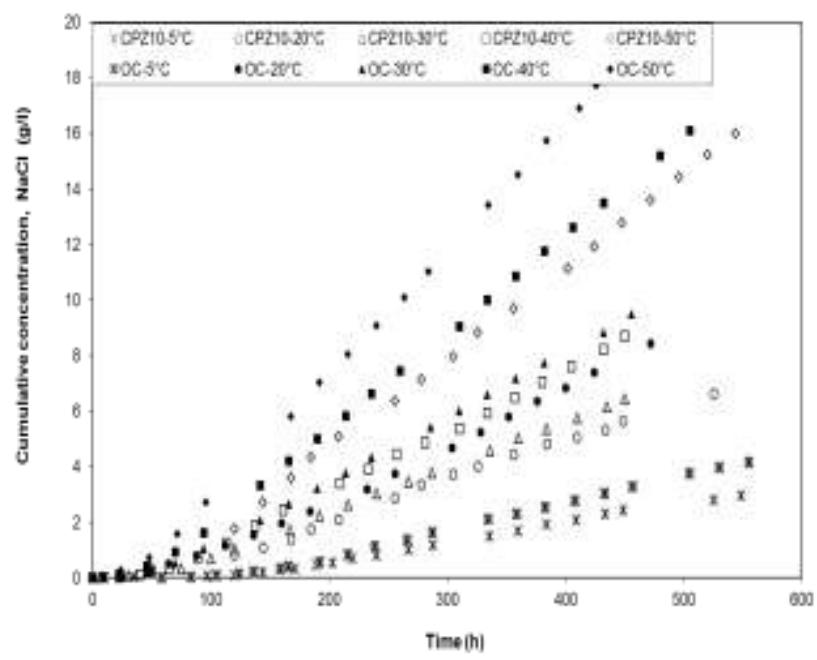

1

Fig. 3-Evolution cumulative increase of chloride concentration in downstream cell of $\mathrm{OC}$ and CPZ10 at different temperatures (Note : $1 \mathrm{~g} / \mathrm{l}=0.0083 \mathrm{lb} / \mathrm{gal}$ ).
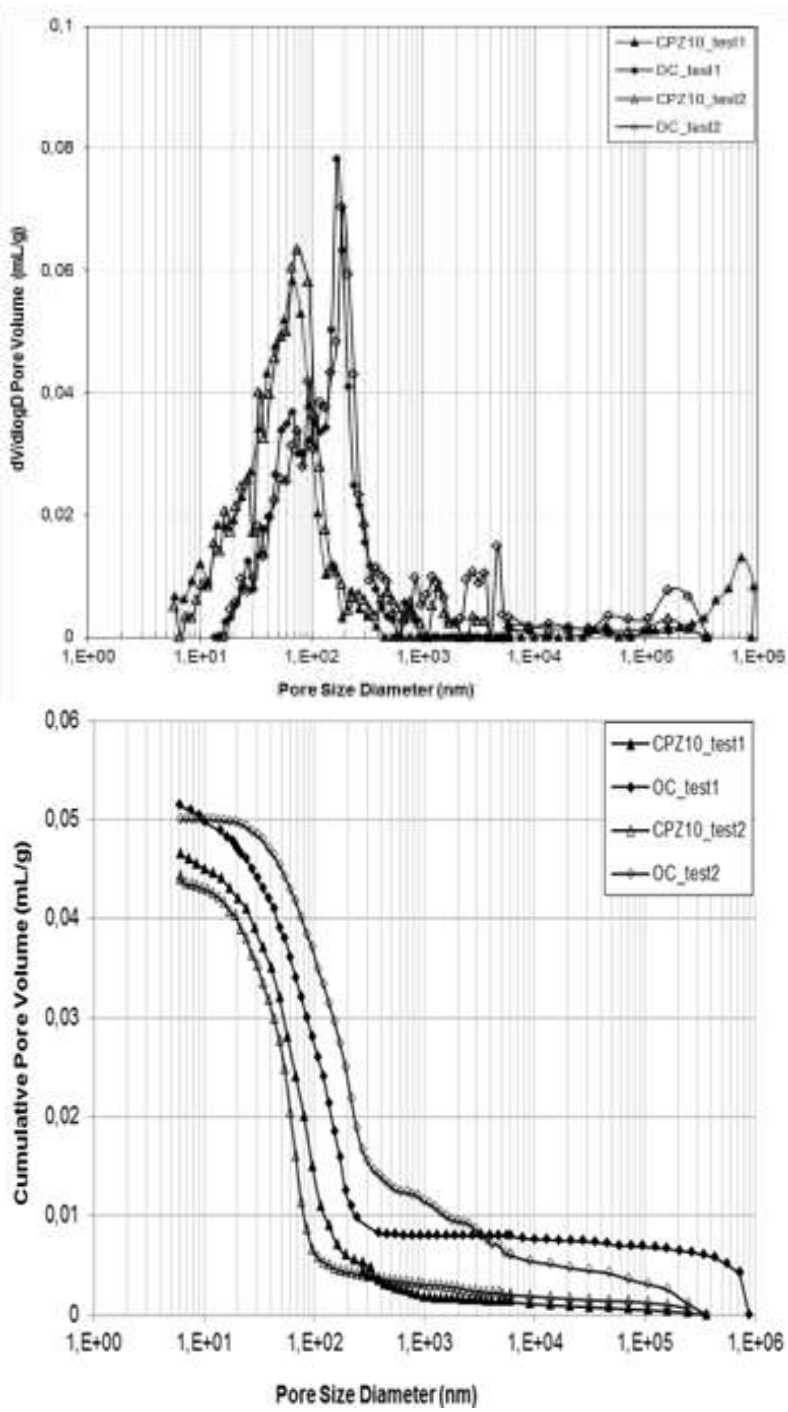


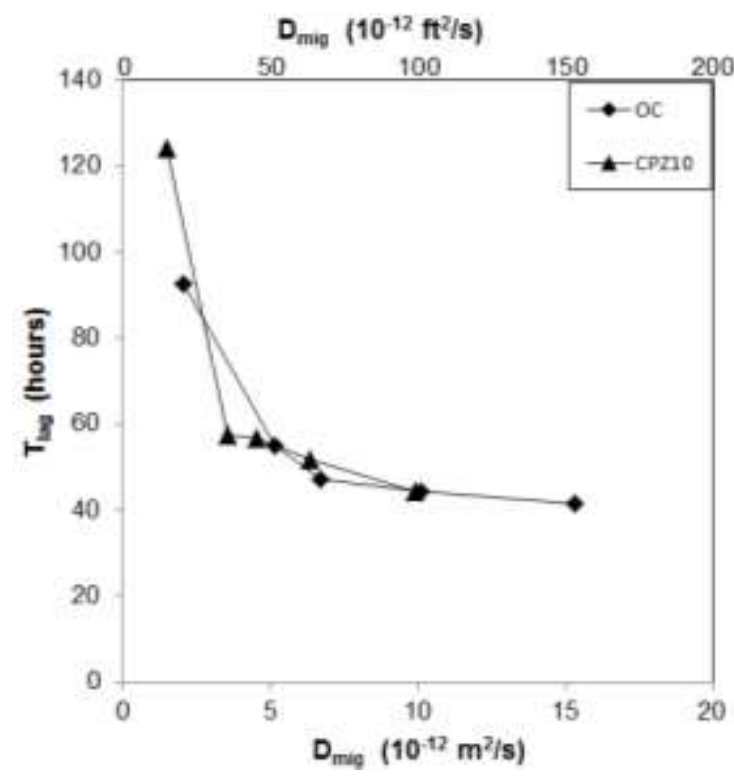

Fig. 5-Relationship between the time lag and the diffusion coefficient of function of the 6 different temperatures.

7

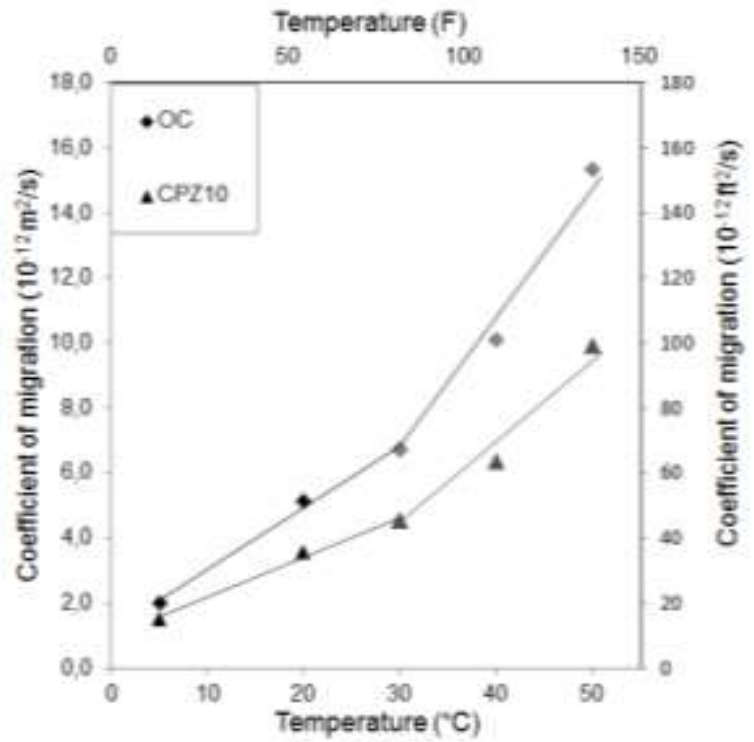

Fig. 6-Chloride diffusion coefficient as a function of temperature. 


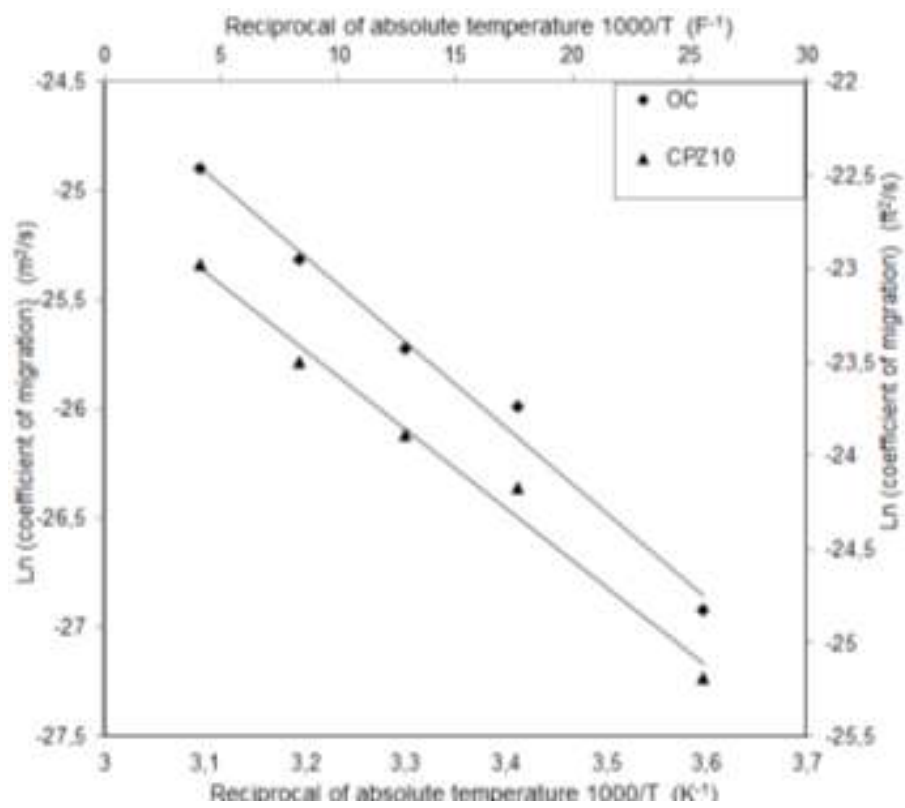

Fig. 7-Arrhenius plots of the diffusivity in concrete mixtures.

3

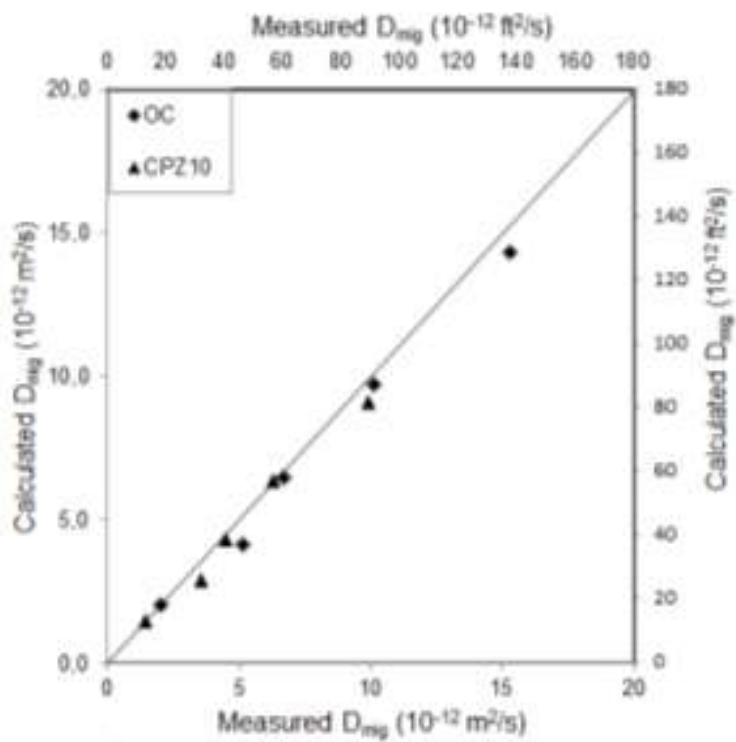

Fig. 8-Comparison between the experimentally obtained and calculated diffusion 